\title{
STUDY OF MID-ARM CIRCUMFERENCE IN INDIAN SCHOOL
} CHILDREN

\section{Kharat Vidya $\mathrm{S}{ }^{* 1}$, Puranik Medha ${ }^{2}$.}

${ }^{* 1}$ Assistant Professor, Department of Anatomy, Bharati Vidyapeeth (Deemed to be University) Medical College, Pune.

${ }^{2}$ Professor, Department of Anatomy, Bharati Vidyapeeth (Deemed to be University) Medical College, Pune.

\section{ABSTRACT}

The objective of our study was to obtain the Anthropometric measurements of body mid- arm circumference, in School going adolescents,9-12 years, boys and girls, contrasting socioeconomic groups and was investigated by cross sectional survey. The cross-sectional study was conducted on School going adolescents (total no-511), Pune, India. We observed that the measurements of mid- arm circumference of Higher income group (HIG) were almost greater than Lower income group (LIG) values in all the age groups. The analysis would be effective to interpret the pattern of growth in adolescents, 9-12 years, which could be altered by social upbringing and economic status in a community.

KEY WORDS: Anthropometry, School Children, Growth pattern, Socio-economic groups.

Address for Correspondence: Dr. Kharat Vidya S, Assistant Professor, Department of Anatomy, Bharati Vidyapeeth (Deemed to be University) Medical College, Dhankawadi, Pune 411043, India. Mobile Number: 09423018816 E-Mail: kharatvidya2@gmail.com

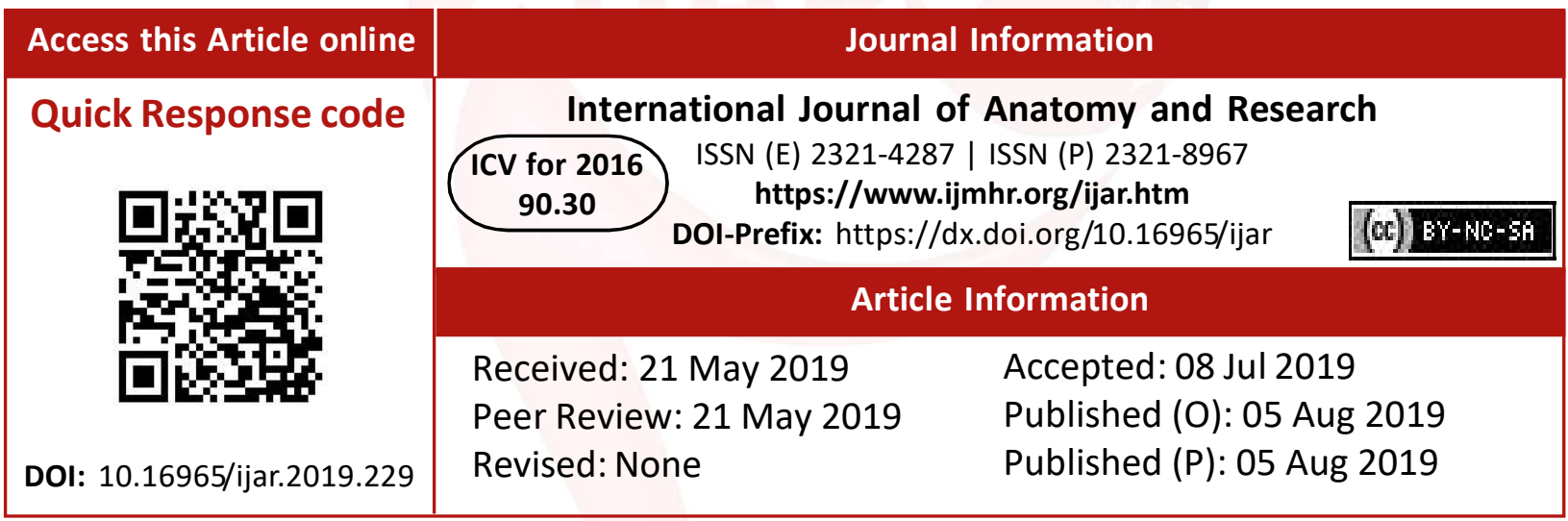

\section{INTRODUCTION}

India being a developing country shows a great diversity in its Socio-economic status .Dietary variation would have an impact on growth pattern. Humans have rapid growth phase immediately after birth, followed by a latent period and again rapid adolescent growth spurt [1]. Adolescence [2] is a period of growth at an accelerated pace.' Growth and Development' is influenced by various factors like nutrition, genetics of an individual, social upbringing and economic standing in a society. Adolescent and childhood growth stages are both significant phases of growth development. Physical metamorphosis in this phase results in discrepancy or in inequality amongst both boys and girls.
This results in a necessity to evaluate the pattern of growth in both genders. Assessing child's growth with Anthropometric measurements is comparatively economical than other health evaluation methods [3].

The survey of nutritional status is of an immense significance for the recognizing the social prosperity of a community [4].

The aim of our study was to obtain the Anthropometric measurements of body mid- arm circumference, in School going adolescents, 9-12 years, boys and girls, contrasting socioeconomic groups and was investigated by cross sectional survey. We observed that the measurements of mid- arm circumference of Higher income group (HIG) were almost greater than 
Lower income group (LIG) values in all the age groups.

\section{MATERIALS AND METHODS}

The cross-sectional study was conducted on School going adolescents (Table no 1), Pune, India. The adolescent students belonged to both girls and boys and both Upper income group/ Higher income group (HIG) and lower socioeconomic status /Lower income group (LIG) [5].

The measurement was taken at mid- point of the tip of the acromion process to the olecranon process. At this point, the mid-arm circumference was measured with the tape slung to the skin but not compressing the soft tissues. Both right and left sides were measured and the average was taken [2].

\section{RESULTS AND DISCUSSION}

As seen in Table no 2 and Graph no 1, the maximum growth in mid-arm circumference was seen at 10-11 years in males and females of HIG. There was a steady growth in Mid -arm circumference in males and females of lower socio-economic group from $9-12$ years. Mean measurements of mid-arm circumference of LIG were lower than those of HIG in the corresponding age groups. In HIG group, in both sexes, there was a growth spurt observed in the age group of $10-11$ years Boys $(20.63 \mathrm{~cm})$ and Girls $(21.06 \mathrm{~cm})$ these values were seen to decrease in 11-12 age group in both genders of HIG Boys $(19.80 \mathrm{~cm})$ and Girls $(20.86 \mathrm{~cm})$. These could be due to the fact that the analysis was on cross-sectional. But in the same cross-sectional study, the LIG group shows the steady growth in mid-arm circumference from $9-12$ years.

A child's growth is definitely acknowledged as an important indicator of health of the community in developing countries. In community based surveys, mid upper arm circumference (MUAC) was seen as a good assessor of undernutrition in children ${ }^{4}$ and also good at predicting mortality [6].

The underprivileged school children are lagging behind their counterparts as they face severe deficits in levels of nutrition and are also face immense environmental and social strains. These facts were seen in our study. Nutritional Anthropometry is one of the most important tools in assessing the nutritional status of a community or a nation, which is of great value in guiding public programs.

It is a well acknowledged fact that changes in dimensions of the body are mainly accounted by changes in nutritional food intake and life style. In the Upper income group children in the urban area, it has been seen that lots of efforts are taken in terms of exercises and food regulation for maintenance of specific desired body dimensions. The values for the above measurements were compared in both genders of HIG and LIG in three age groups.

Our data showed a variation because the comparative data comes from heterogeneous parts. However, the overall temporal changes were clearly observable from these tables. A few discrepancies were observed in measurements. This was because the selection of the school children was based on only one criterion that is economic status. The fluctuations that we observed here in different age groups could be due to sampling error.

Our study was statistically analyzed by using ' $Z$ ' test for significance and was presented in the following tables (Tables no 3 and table no 4)

Z-test used for comparison of the two contrasting socioeconomic groups showed the $p$-value was $<0.05$, indicating that there was relevant contrast between the two groups. Similarly ' $\mathrm{Z}$ ' test used for comparison between males and females also showed that the $p$-value was $<0.05$, indicating that there was important and relevant contrast between the Males and Females.

Table 1: Distribution of School going students.

\begin{tabular}{|c|c|c|c|c|}
\hline \multirow{2}{*}{$\begin{array}{c}\text { Age } \\
\text { (years) }\end{array}$} & \multicolumn{2}{|c|}{ MALE } & \multicolumn{2}{c|}{ FEMALES } \\
\cline { 2 - 5 } & HIG & LIG & HIG & LIG \\
\hline $09-10$ & 42 & 42 & 42 & 42 \\
\hline $10-11$ & 42 & 42 & 42 & 42 \\
\hline $11-12$ & 42 & 42 & 42 & 49 \\
\hline Total & 126 & 126 & 126 & 133 \\
\hline
\end{tabular}

(Total no. 511 Males: 252 Females: 259)

Table 2: Measurements of mid-arm circumference.

\begin{tabular}{|c|c|c|c|c|c|c|c|}
\hline \multirow{2}{*}{$\begin{array}{c}\text { Mid-arm } \\
\text { circumference }(\mathrm{cm})\end{array}$} & \multicolumn{2}{|c|}{9 -10yrs } & \multicolumn{2}{c|}{ 10-11yrs } & \multicolumn{2}{c|}{ 11-12yrs } \\
\cline { 2 - 8 } & Males & Females & Males & Females & Males & Females \\
\hline \multirow{2}{*}{ LIG } & Mean & 17.02 & 15.71 & 17.25 & 17.91 & 17.74 & 19.06 \\
\cline { 2 - 8 } & S.D & 1.05 & 0.92 & 2.02 & 1.76 & 1.55 & 2.49 \\
\hline \multirow{2}{*}{ HIG } & Mean & 18.8 & 18.01 & 20.63 & 21.06 & 19.8 & 20.86 \\
\cline { 2 - 8 } & S.D. & 2.36 & 1.69 & 2.17 & 2.31 & 2.05 & 1.63 \\
\hline
\end{tabular}


Table 3: ' $\mathrm{Z}$ ' test analysis for comparison between low and high socio-economic group.

\begin{tabular}{|c|c|c|c|}
\hline \multicolumn{3}{|c|}{$\begin{array}{l}\text { Comparison Between LOW and HIGH socio- } \\
\text { economic group }\end{array}$} & $\begin{array}{c}\text { Mid-arm } \\
\text { circumference }\end{array}$ \\
\hline \multirow{6}{*}{$9-10$ years } & \multirow{3}{*}{ Males } & $Z$ value & 3.88 \\
\hline & & $p$-value & 0 \\
\hline & & Significance & $\mathrm{HS}$ \\
\hline & \multirow{3}{*}{ Females } & $Z$ value & 6.18 \\
\hline & & $p$-value & 0 \\
\hline & & Significance & $\mathrm{HS}$ \\
\hline \multirow{6}{*}{$10-11$ years } & \multirow{3}{*}{ Males } & $Z$ value & 6.25 \\
\hline & & $p$-value & 0 \\
\hline & & Significance & $\mathrm{HS}$ \\
\hline & \multirow{3}{*}{ Females } & $Z$ value & 5.69 \\
\hline & & p-value & 0 \\
\hline & & Significance & $\mathrm{HS}$ \\
\hline \multirow{6}{*}{$11-12$ years } & \multirow{3}{*}{ Males } & $Z$ value & 4.08 \\
\hline & & $p$-value & 0 \\
\hline & & Significance & $\mathrm{HS}$ \\
\hline & \multirow{3}{*}{ Females } & $Z$ value & 3.63 \\
\hline & & $p$-value & 0.0001 \\
\hline & & Significance & HS \\
\hline
\end{tabular}

(HS: Highly Significant S: Significant NS: Not significant) Table 4: ' $Z$ ' test analysis for comparison between Males and females.

\begin{tabular}{|c|c|c|c|}
\hline \multicolumn{3}{|c|}{$\begin{array}{l}\text { Comparison Between Males and } \\
\text { females }\end{array}$} & $\begin{array}{c}\text { Mid-arm } \\
\text { circumference }\end{array}$ \\
\hline \multirow{6}{*}{$9-10$ years } & \multirow{3}{*}{ LIG } & $Z$ value & 1.88 \\
\hline & & $p$-value & 0.04 \\
\hline & & Significance & $\mathrm{S}$ \\
\hline & \multirow{3}{*}{ HIG } & $Z$ value & 3.18 \\
\hline & & $p$-value & 0 \\
\hline & & Significance & $\mathrm{HS}$ \\
\hline \multirow{6}{*}{$10-11$ years } & \multirow{3}{*}{ LIG } & $Z$ value & 0.85 \\
\hline & & $p$-value & 0.25 \\
\hline & & Significance & NS \\
\hline & \multirow{3}{*}{ HIG } & $Z$ value & 1.69 \\
\hline & & p-value & 0.044 \\
\hline & & Significance & $\mathrm{S}$ \\
\hline \multirow{6}{*}{$11-12$ years } & \multirow{3}{*}{ LIG } & $Z$ value & 2.08 \\
\hline & & $p$-value & 0.003 \\
\hline & & Significance & $\mathrm{HS}$ \\
\hline & \multirow{3}{*}{ HIG } & $Z$ value & 3.63 \\
\hline & & $p$-value & 0.0001 \\
\hline & & Significance & $\mathrm{HS}$ \\
\hline
\end{tabular}

(HS: Highly Significant S: Significant NS: Not significant)

Graph 1: Distribution of mid-arm circumference.

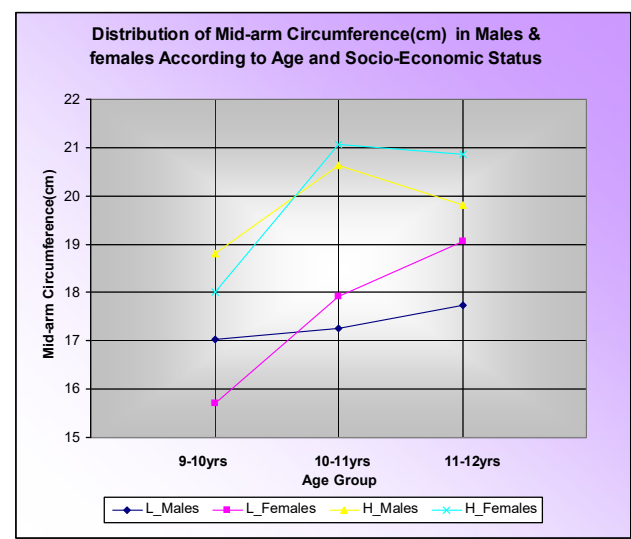

L- Lower Socio-economic group H - Higher Socioeconomic group

\section{CONCLUSION}

Our analysis inferred that different age groups showed variations in rate of growth in LIG and HIG. Both genders in the above age and socioeconomic groups showed a relevant contrast. In HIG, growth spurt in mid-arm circumference, was earlier at 10-11 years in both males and females, which showed decrease thereafter in the above values in 11-12 years groups. While steady increase in the growth was observed in the mid-arm circumference in Males and Females of LIG. Thus, the of growth in mid-arm circumference is similar in HIG and LIG. In our study we had observed that HIG values are always greater than LIG values in all the age groups.

The analysis would be effective to interpret the pattern of growth in adolescents, 9-12 years, which could be altered by social upbringing and economic status in a community.

\section{Conflicts of Interests: None}

\section{REFERENCES}

[1]. Standring S, Gray's Anatomy. The anatomical basis of clinical practice; 39th ed. Edinburg, Elsevier, Churchill Livingstone; 2005;211-223.

[2]. K. E. Elizabeth. Nutrition and Child development; 2nd ed., Paras Medical Publisher; 2002;37-184.

[3]. Mohammad Asaduzzaman, Shamima Akter, Md. Anisuzzaman, Md. Abdullah Al Masud,Md. Ahasan Habib, Sonia Alam Joya1, Rehana Akter Sumaya, Farha Matin Julianaand Md. Jahangir Alam . Assessment of nutritional status among 6-60 months old children in rural Bangladesh, European journal ejbps, 2018;5(5):129-137.

[4]. Sadaruddin Biswas, Kaushik Bose, Ashish Mukhopadhyay, Mithu Bhadra. Mid-upper Arm Circumference Based Undernutrition among Bengalee Children of Chapra, West Bengal, India, Iran J Pediatr, March 2010;20(1):63-68.

[5]. Dr.Sheikh Mohd Saleem. Modified Kuppuswamy Scale Updated For Year 2018, Paripex - Indian Journal Of Research, March 2018; 7 (3):217-218.

[6]. Prithviraj Karak, Rajkumar Maiti, Priya Das and Anushree Karmakar .Asessment of nutritional status of school children in rural and urban areas of Bankura, West Bengal, IJPSR 2018;9(1):338-345.

How to cite this article: Kharat Vidya S, Puranik Medha. STUDY OF MID-ARM CIRCUMFERENCE IN INDIAN SCHOOL CHILDREN. Int J Anat Res 2019;7(3.2):6804-6806. DOI: 10.16965/ijar.2019.229 